\title{
Fluctuation in wells/tube wells water table of Dev Bhumi Dwarka district of Gujarat
}

\author{
J.V. Polara*, B. M. Hadiya and A.V. Rajani \\ Department of Agricultural Chemistry and Soil Science, Junagadh Agricultural University, \\ JUNAGADH (GUJARAT) INDIA (Email : jvpolara@jau.in; b.m.hadiya22@gmail.com;avrajani@jau.in)
}

\begin{abstract}
In order to study the fluctuation of wells/tube wells water table, 30 sites each from 4 talukas of Dev Bhumi Dwarka district from where water table depths were measured before and after monsoon. In all, 94 wells and 26 tube wells water table levels were studied in May, 2015 and again after $6^{\text {th }}$ month in November, 2015. The water table before monsoon (May, 2015) in wells and tube wells ranged from 3.05 to 27.44 and 6.71 to 192.1 with mean value of 15.56 and $75.99 \mathrm{~m}$, respectively. At the end of the monsoon (November, 2015), the overall water table of Dev Bhumi Dwarka district in well ranged from 1.83 to 18.29 and in tube well from 5.49 to $51.83 \mathrm{~m}$ with mean value of 5.79 and $21.39 \mathrm{~m}$, respectively. The minimum fluctuation of water table of well $(7.72 \mathrm{~m})$ and tube well $(21.55 \mathrm{~m})$ was observed in Dwarka taluka. The maximum fluctuation of water table in well $(12.73 \mathrm{~m})$ and tube well $(104.37 \mathrm{~m})$ was observed in Bhanvad taluka.
\end{abstract}

Key Words : Water table fluctuation, Well/tube well, Water table

View Point Article : Polara, J.V., Hadiya, B.M. and Rajani, A.V. (2018). Fluctuation in wells/tube wells water table of Dev Bhumi Dwarka district of Gujarat. Internat. J. agric. Sci., 14 (1) : 244-246, DOI:10.15740/HAS/IJAS/14.1/244-246.

Article History : Received : 24.06.2017; Revised : 11.12.2017; Accepted : 23.12.2017

\footnotetext{
* Author for correspondence:
} 